\title{
Chronic pain disability in the workplace
}

Robert W Teasell BSc MD FRCPC, Harold Merskey DM FRCP(Lond) FRCPC FRCPsych

\author{
RW Teasell, H Merskey. \\ Chronic pain disability in the workplace. \\ Pain Res Manage 1997;2(4):197-205.
}

Chronic pain disorders have been associated with increasing disability expenditures in Western industrialized countries. The reason for this increase is unknown. Many chronic pain disorders have been characterized by a lack of readily demonstrable pathology, resistance to treatment and associated psychosocial difficulties. The difficulties inherent in the diagnosis and treatment of chronic pain disorders are compounded by problems in determining disability and entitlement to compensation. Recent attempts to label chronic pain disorders as solely psychosocial issues to the exclusion of biological issues appear to be misguided, particularly in the light of recent evidence supporting an organic etiology in several chronic pain conditions. Such an approach will disproportionately affect those in lower socioeconomic groups in an effort to contain costs. The long term cost to society of targeting a highly vulnerable group with such an approach remains to be determined.

Key Words: Biological mechanisms, Chronic pain, Cost containment, Disability, Psychosocial factors

\section{Incapacité causée par la douleur chronique en milieu de travail}

RÉSUMÉ : Les troubles liés à la douleur chronique sont associés à une augmentation des dépenses relatives à l'incapacité dans les pays occidentaux industrialisés. La raison de cette augmentation reste inconnue. De nombreux troubles liés à la douleur chronique sont caractérisés par une absence de pathologie facilement démontrable, une résistance au traitement et des difficultés psychosociales associées. Les difficultés inhérentes au diagnostic et au traitement des troubles liés à la douleur chronique sont aggravées par des difficultés à déterminer l'incapacité et 3 le droit à recevoir des indemnités. Les tentatives récentes pour étiqueter les troubles liés à la douleur chronique seulement comme une question entièrement psychosociale à l'exclusion d'une cause biologique ne semblent pas pertinentes, surtout à la lumière des preuves récentes qui témoignent en faveur d'une étiologie organique dans plusieurs troubles douloureux chroniques. Ce type d'approche visant à maîtriser les coûts pénalisera de façon disproportionnée les personnes appartenant à des groupes socio-économiques défavorisés. Il reste à déterminer quels seront à long terme les coûts sociaux engendrés par ce type d'approche visant à cibler un groupe d'individus très vulnérable.
$\mathrm{D}$ enial of the validity of chronic pain syndromes as clinical or biological entities and recent attempts to classify chronic pain disorders as solely psychosocial issues run the risk of hurting those patients who can least afford it, for example, individuals who perform jobs with heavier demands, are less well educated and are in a lower socioeconomic class. This article discusses the effects of targeting this highly vulnerable group.

\section{DISABILITY ASSOCIATED WITH CHRONIC PAIN} The rise in disability claims

Chronic pain is an immense health care problem, affecting approximately 65 million Americans in 1982 (1). Of patients suffering from chronic pain, $6 \%$ to $10 \%$ are work-disabled (2). Disability is defined as "any restriction or lack ... of ability to perform an activity in the manner or within the range considered normal for a human being"

This article is being published simultaneously in Pain Forum (1997;6:1-11)

Physical Medicine and Rehabilitation, University Hospital, University of Western Ontario, London, Ontario

Correspondence and reprints: Dr Robert Teasell, University Hospital, 339 Windermere Road, London, Ontario N6A 5A5. Telephone 519-663-3235, fax 519-663-2941 
(3). Concerns about the fiscal cost of disability have arisen as disability expenditures related to low back pain (LBP) reportedly grew by $14.3 \%$ per year from 1970 through 1986 in the United States (4). It is not clear how much these figures have been corrected for inflation; increases in real wages; alterations in the sex and age composition of the workforce; and total increase in the number of workers as a result of immigration and more women entering the work force. Other factors contributing to the increase may include an increasing acceptance of chronic pain as a disabling disorder, changing public attitudes regarding the need to work despite being in pain, the availability and expectation of compensation payments, a more demanding and uncompromising workplace, greater empowerment of injured individuals, psychophysiological reactions to heightened societal stress and a decrease in the availability of alternative work, especially for unskilled workers. Fordyce (5) outlines the personal and economic costs of increased disability assignment and notes that if current trends continue, disability programs may go bankrupt. It has even been suggested that the system designed to care for disabled patients with chronic pain disorders may actually be exacerbating the problem (5) through an expectation of compensation (6).

\section{The Report on Back Pain in the Workplace}

A Task Force on Back Pain in the Workplace was commissioned by the International Association for the Study of Pain to suggest solutions to the apparent marked increase in disability-related costs due to nonspecific LBP (NSLBP) in economically developed countries (5). The Task Force's recommendations were based on the premise that "impairment and permanent disability should be restricted to conditions for which causation has been demonstrated" (5). However, the recommendations were based on the assumption that the presence of nociception could only be determinable if specific radiologic abnormalities were present. The authors argued that back pain that was not surgically correctable, had been treated with normal measures for six weeks and had not improved should no longer be regarded as an illness or treated as disabling. The presumption was that pain in NSLBP (defined as pain in the absence of radiographic markers) was not valid in terms of nociception and disability. NSLBP and subsequent disability were presented as largely behavioural problems, fostered by inappropriate medicalization and a willingness to compensate pain.

The Task Force suggested comprehensive re-evaluation, including social and vocational assessment components in cases where function had not been restored and return to work not achieved. They recommended that for almost all cases pain be reconceptualized as 'activity intolerance' and disability as 'unemployment'. This reconceptualization avoided the issue of what the patient was actually experiencing when he or she complained of pain. Designating disability as unemployment allows termination of benefits once the usual period of unemployment income replacement comes to an end, regardless of whether the patient remains disabled. This report basically recommended that a time limit be placed on disability payments in order to control costs while denying the reality of chronic pain by replacing it with the term 'activity intolerance'. Injured workers are, of course, not the only individuals who will suffer from such an approach. Patients injured in motor vehicle accidents who receive so-called soft tissue injuries affecting the neck are particu- larly liable to develop chronic pain. According to the Quebec Task Force on Whiplash-Associated Disorders the recommended period for compensation and rehabilitation is a mere 27 days (7).

Concerns about the fairness and utility of such cost containment measures are the subject of this paper. We will look first at the accumulating evidence for the organic causation of common chronic pain clinical entities, discuss the role of key psychosocial factors and, finally, examine who will be most affected by proposed changes.

\section{ARE THE INJURIES OR PAIN REAL?}

\section{Clinical classification controversies}

Chronic pain disorders are common, with diagnoses being made on the basis of clinical criteria. Some of these complaints, such as whiplash injuries and chronic LBP, have readily recognizable presentations. Classification criteria for the fibromyalgia syndrome have been proposed by the American College of Rheumatology (8) and have become widely accepted. Other entities, such as repetitive strain injury or myofascial pain syndrome, have proven more difficult to define $(9,10)$. Where definitions exist they are often met with incredulity $(11,12)$. Scepticism has mainly developed because the pathophysiology of these conditions remains largely unknown. For instance, a patho-anatomical or pathophysiological explanation cannot be offered in over $85 \%$ of cases of LBP (13). This scepticism culminated in a back pain report by Fordyce (5) and his recommendation that NSLBP be reconceptualized "as a problem of activity intolerance and not a medical problem".

\section{Recovery after trauma}

Many chronic pain disorders originate from a trauma. Much of the debate regarding persistent pain revolves around the normal anticipated time for musculoligamentous healing to occur. The Quebec Task Force on Whiplash-Associated Disorders noted, "apart from anatomic studies, much of the scientific understanding of soft tissue injury and healing is derived from animal models, and there is little information on the normal recuperation period. In the animal model of soft tissue healing, there is a brief period (less than 72 hours) of acute inflammation and reaction followed by a period of repair and regeneration (approximately 72 hours to up to 6 weeks) (sic), and finally by a period of remodelling and rematuration that can last up to one year" (7). Although some animal studies suggest complete tissue repair should occur, others, such as those of Macnab (14), have long demonstrated evidence of important physical alterations that could become sources of chronic pain. In humans, a significant number of individuals continue to suffer chronic pain. Musculoligamentous injuries about the shoulder joint (rotator cuff disorders), ankle joint (lateral ligamentous instability) or knee joint (cruciate ligamentous tears), to name a few, are well recognized and accepted, and yet defy the above models of healing in individuals who go on to chronicity. Alternatively, sports medicine clinics could be redefined as clinics for the 'high activity intolerant'.

\section{Evidence of an organic origin of chronic pain}

Whiplash injuries: Cervical sprain injuries (whiplash) due to rearend collisions are the most common type of complaints from motor vehicle accidents attributed to soft tissue injuries. Such injuries are liable to result from collisions occurring at upwards of $8 \mathrm{~km} / \mathrm{h}$; 
women are more often affected than men; and pain may appear immediately or gradually (as a rule over $48 \mathrm{~h}$ ). Besides neck pain, whiplash symptoms frequently include neck stiffness, headache, dizziness and difficulty in concentration. Most patients show steady improvement but a significant proportion continue to suffer from chronic neck pain. Both acute and chronic whiplash injuries are remarkably consistent in terms of their clinical presentation.

Macnab's work (14) with anesthetized monkeys demonstrated an impressive series of injuries on autopsy including hematomata in muscles, ligamentous tearing, partial separation of discs from the anterior longitudinal ligament and damage to the zygapophyseal or facet joints. Macnab (14) also outlined a mechanism of injury involving neck hyperextension. The United States Department of Transportation recognized whiplash injuries as a major public health problem when they required all passenger cars manufactured after December 31, 1968 to be equipped with head restraints for front seat occupants. More recently, Barnsley et al (15) provided strong evidence of facet joint involvement in many chronic whiplash injuries by utilizing placebo-controlled injections of local anesthetics. Twenty-seven of 38 patients studied obtained complete relief of pain following each of two local blocks of the symptomatic joint, and each obtained longer lasting relief with the longer-acting drug (bupivacaine) than the shorter-acting medication (lignocaine). A variety of other studies had come to a similar conclusion based on identification of tears at the joint capsules at operation, postmortem examinations, cadaver studies and animal experiments. Taylor and Twomey (16) did an autopsy comparison of the cervical spines of younger subjects who died of major trauma with those of subjects who died of natural causes. They found that, in the trauma subjects, discogenic and facet joint lesions were abundant, but absent in the nontrauma group. Sturzenegger and colleagues (17) studied whiplash patients one week and again at one year postaccident. They noted that the accident mechanism and initial findings at one week suggestive of a more severe injury - were significantly related to the persistence of symptoms at one year. Although studies of treatment are still limited there are indications that radiofrequency coagulation may effectively relieve cervical zygapophyseal joint pain for periods in excess of six months (18).

Fibromyalgia: With fibromyalgia there is conflicting evidence regarding natural history, especially eventual outcome and whether it can occur following trauma (19-22). However, mounting research in the fibromyalgia syndrome clearly points to biochemical abnormalities such as derangements of serotonin metabolism and disturbances in hormone secretion, particularly to high levels of substance $\mathrm{P}$ in the cerebral spinal fluid (23-27). Three independent studies $(26,28,29)$ have demonstrated levels of substance $P$ in the cerebral spinal fluid two to three times that in normal controls.

Experimental evidence of a central neurological origin for regional pain: There is abundant evidence of neuronal plasticity in the spinal cord in response to external stimuli (30). Likewise, Mense (31) has recently reviewed the theoretical and experimental basis for referred pain arising from muscle. Unlike cutaneous pain, which is very accurately localized, muscle pain in humans is more diffuse and often referred to regions remote to muscle (32-35). Regional pain syndromes refer to conditions in which painful areas extend beyond a single dermatome or musculoligamentous structure, tending to involve wider regions of the body. Mense (31) describes animal experiments in which persistent nociceptive input from muscle (in the form of an experimental myositis) results in an expansion of rat dorsal horn neurons responding to electrode stimulation of peripheral nerves. This indicates that the population of neurons that can be activated by afferents from that muscle increases in size over time. The spread of excitability or central sensitization to adjacent neuron populations in the dorsal horn may result in the sensation of spreading or radiating pain. The mechanism appears to involve release of neurotransmitters from spinal terminals of nociceptive muscle afferent fibres (36). This work matches earlier findings with cutaneous and muscle afferents influencing spinal plasticity (30).

In experimental work where substance $\mathrm{P}$ was administered iontophoretically at high concentrations in the dorsal horn, activation of nociceptive neurons at low concentration occurs and leads to long lasting depolarization of the cell membrane $(37,38)$. In contrast to amino acid neurotransmitters, substance $\mathrm{P}$ is regarded as a volume neurotransmitter (39) that is capable of influencing large populations of neurons in the vicinity of the release site. This property may be important for the induction of widespread changes in dorsal horn excitability during experimental myositis. Substance P is not the only neurotransmitter that may induce the observed effects. Other neuropeptides and excitatory amino acids capable of causing similar changes in dorsal horn excitability have been described (40).

These data and a growing body of evidence have established a well documented neurophysiological basis for the persistence of 'soft tissue pain'. It therefore appears to be presumptuous to claim, on the basis of selected experimental animal studies, that all injured patients should get better, particularly in the face of repeated clinical evidence to the contrary. As our understanding of pain, and in particular chronic pain, continues to expand, the hypothesis that all soft tissue injuries should heal has become increasingly less plausible.

\section{WHAT IS THE ROLE OF PSYCHOSOCIAL FACTORS?}

Are psychological factors causative?

There is an appropriate trend in the current literature towards understanding chronic pain within a biopsychosocial framework. Biopsychosocial conceptualizations are important in any chronic illness, including other painful disorders such as rheumatoid arthritis. However, the biopsychosocial approach is often used to avoid any quantitative evaluation of the extent to which problems in a particular individual may be attributed to one factor or another. Associated psychosocial difficulties, no matter how minor, are often regarded as causative of chronic pain and disability, while biological/organic sources of pain are ignored, in part because they often cannot be definitively identified by that examiner. In chronic pain sufferers, whether a particular psychological feature is causative of the pain or occurs as a consequence needs to be determined. Gamsa (41), in a study of large numbers of patients with chronic pain in different centres, provided evidence that psychological changes were more a consequence of pain than attributable to premorbid characteristics. Clinically, if an attribution cannot be made this should be recognized and admitted.

The vast majority of literature linking chronic pain with psychological factors has demonstrated only correlational relationships when looking at patients referred to specialty-based practices. Such a referral group has a significant inherent bias heavily favouring pa- 
tients with psychopathology who are more likely to be sent to a tertiary care clinic. Crook and Tunks (42) have shown that patients in pain clinics differ significantly from patients in the general population; the former are more likely to have been injured, report more intense and more constant pain, have more difficulties with activities of daily living, are more depressed and withdrawn socially, and show more long term consequences due to unemployment, litigation and substance abuse. Merskey et al $(43,44)$ showed that psychological findings varied in different clinics, being least in a dental clinic and increasing through a headache clinic, nerve block clinics and a psychiatrist's pain service. Several studies have indicated that unemployment is a better indicator of the occurrence of psychological changes than compensation status (45-47). It would be easy to misinterpret this association as meaning that psychological factors are responsible for unemployment. Unfortunately, the substantial volume of correlational evidence generated from pain clinics or specialty practices is often interpreted as proof that chronic pain is a consequence of psychosocial factors or 'less effective repertoires' (5). The fact that psychological disorders are frequently encountered in association with chronic pain has not been adequately explained, and for individual patients may be cause, effect or both.

Chronic pain syndromes such as NSLBP are not unique in terms of being associated with psychosocial factors. Rheumatoid arthritis patients have been shown to have high levels of anxiety and depression compared with nonarthritic medical patients and healthy controls (48-50); in turn, it has been suggested that these psychological factors contribute to rheumatoid arthritis pain and functional disability independently of disease activity $(51,52)$. In patients who have suffered spinal cord injuries, psychosocial variables were associated with chronic pain (53), and in one large survey $36.3 \%$ of individuals with spinal cord injuries who stopped working after their spinal cord injury reported that it was the severity of their pain and not their paralysis that stopped them from working (54).

Despite the foregoing, psychosocial factors continue to be regarded by some as critical to the transition from acute to chronic pain disorders (55). Discordances among pain, impairment and disability; the observation that healing occurs in the majority of cases; ignorance of pathophysiological correlates to chronic pain; and the aforementioned correlational evidence of the presence of psychosocial phenomena have led to the belief that psychosocial factors cause patients to develop chronic pain and disability. Two studies in this regard are particularly relevant because both attempted to deal with the issue of correlational data by studying patients during the acute phase and thereby limiting selection biases.

Gatchel et al (56) studied a cohort of 421 patients referred to three Texas clinics by using a standard battery of psychosocial assessment tests within six weeks of the onset of acute back pain. Later, logistic regression analyses, conducted to differentiate between patients who were back at work after one year versus patients who were not, found a correlation with four items: self-reported pain and disability; scores on scale 3 of the Minnesota Multiphasic Personality Inventory (MMPI); Workmen's Compensation Board and personal injury insurance status; and female sex. The authors saw this finding as evidence that psychosocial factors were associated with injured workers likely to develop chronic low back disability. However, it could be argued that much of the effect can also be accounted for by the severity of pain; the MMPI may simply be an indicator of somatic pain severity $(43,57,58)$, while the presence of compensation may have been associated with more severe injuries. Indeed, the study reported that "major pathophysiology, such as depression and substance abuse, was not found to be a precursor or predictive of chronic disability. Such data are important in indicating that the high rates of psychopathology seen in chronic pain disability conditions develop as a result of the chronicity and do not cause it" (56). The study was interpreted by the authors as revealing "that major psychopathology did not precede or cause the development of chronic pain disability" (56).

Radanov et al (59) looked at whiplash patients referred for purposes of their study by family doctors following a common whiplash injury in Switzerland. The patients were all insured under a no-fault insurance plan with no compensation for noneconomic loss (pain and suffering). Of 164 consecutive patients referred, $27 \mathrm{did}$ not meet the criteria and 20 patients dropped out at six months. A total of 117 subjects (74 women) therefore qualified for and completed the study, which went on for one year. Within 10 days of their injury these patients underwent a neurological evaluation, a semistructured interview, self-rating of patients' well-being and subjective cognitive ability, and personality traits including neuroticism, nervousness, aggressiveness, passivity and depression. The mean time between the accident and baseline examination was 7.4 days (SD 4.2 days). At the three-month follow-up examination, $56 \%$ of the patients had completely recovered, and at six months $69 \%$ had no symptoms. No patient in the study was involved in litigation. Patients who were symptomatic and asymptomatic at six months scored within the normal range at baseline on personality scales (using the Freiberg Personality Inventory) with no difference between the groups on any scale. The result indicated that, "(1) the disposition of patients (personality traits) does not primarily influence the course of recovery from common whiplash; (2) psychological and cognitive problems of patients with common whiplash may rather be seen as correlates of somatic symptoms; and (3) injury related psychological and cognitive difficulties can initiate a vicious circle, which may explain the secondary neurotic reaction...." (59). The authors also noted that for whiplash-injured subjects there was little evidence, in their prospectively conducted study, that psychological problems unrelated to the trauma predicted who would recover from whiplash injuries.

\section{Secondary gain and compensation}

The controversy regarding chronic pain and disability is inevitably tied to the concepts of secondary gain and the availability of compensation. The issue of compensation as an important factor in chronic pain disability was advanced by Miller (60) with respect to 'minor head injury' in a carefully selected group of 50 patients (out of a series of 2000) where he argued, based on his own follow-up of a group of claimants seen in his medicolegal practice, that, in effect, they all got better after the settlement of their cases. Despite the obvious methodological flaws, Miller's work was very influential. This argument was eventually rebutted by Mendelson (61) who demonstrated that 10 studies conducted since 1945 had all failed to confirm Miller's reported findings with respect to several types of compensable injury, in that they reported a large number of patients who had not improved after settlement. The notion that patients' pains improve and they return to work shortly after the final settle- 
ment of compensation claims remains unfounded (61). In those who did eventually return to work there was a trend towards less physically demanding and lower-paying jobs, with the majority failing to return to preinjury employment status (61). More recently, Rohling et al (62) conducted a meta-analysis of 32 studies that compared compensated patients with noncompensated patients. Compensation status accounted for only $6 \%$ of the variance in pain experience. Withdrawal or limitation of compensation will certainly help to contain costs but will do so at the expense of those who suffer from chronic pain.

Secondary gain, a vague, all-encompassing term that also includes the effect of compensation, suggests that the individual is somehow rewarded economically, physically or emotionally as a consequence of having an illness. Because secondary gain has not been well defined it has proven difficult to study $(63,64)$. Fishbain (63) noted that one difficulty was inappropriately equating the presence of secondary gain factors and disability with malingering; hence, any potential benefit (such as disability payments or a concerned family member) casts suspicion on the legitimacy of the recipient. The resultant suspicion of the chronic pain patient may overtly or covertly interfere with treatment. Treatment failures are then blamed on secondary gain. Adaptive responses to chronic pain (ie, accepting a certain level of disability and appropriately pacing activities) may also be misinterpreted as secondary gain (63). Yet all, or almost all, illnesses have some associated secondary gain. The identification of presumed secondary gain "does not necessarily mean that secondary gain had an etiological or reinforcing effect on the chronic pain", an error referred to as 'overinference' (63).

The suggestion of secondary gain as causing or perpetuating chronic pain is infuriating for patients who cannot work because of pain and who are well aware that they would be better off financially continuing with their employment rather than living on disability pensions or the uncertain hope of legal proceedings. A concept well known to chronic pain specialists, but rarely mentioned in conjunction with secondary gain, is that chronic pain patients suffer very significant secondary losses (63). The inability to work brings with it frustration, boredom, anxiety, depression and a significant loss of social status. Family and marital stressors inevitably develop. Few 'win the lottery', as some would assert. Often large settlements, when they occur, follow a disastrous period of poverty, including loss of the home, after benefits have been withdrawn or reduced. Hence, the concept of secondary gain must be balanced with that of secondary loss. It has been noted that "the chronic pain patient incurs a large number of secondary losses as a result of allegedly seeking secondary gain and yet the patient appears to act in spite of these potential secondary losses" $(63,64)$. In cases where secondary losses outweigh secondary gains the utility of secondary gain as an etiological factor in the persistence of pain or disability must be viewed with scepticism.

\section{Job satisfaction}

Lack of definitive evidence that psychological factors cause chronic pain or that compensation leads to its perpetuation has caused researchers to focus on a new social dimension, job dissatisfaction, as a major factor in the development of pain complaints and eventual disability. In other words, individuals who are dissatisfied with their work environment are more likely to complain of pain and presuma- bly disability. Bigos et al $(65,66)$ conducted a large prospective study of industrial workers at the Boeing Company. Workers were followed for approximately four years. The study has been widely quoted as indicating that one of the most important factors in development of back pain is the satisfaction of the employee with his or her job. A total of 279 of 3020 studied workers reported back pain in this longitudinal study. Subjects who stated they 'hardly ever' enjoyed their job tasks were 2.5 times more likely to report a back injury $(\mathrm{P}=0.0001)$ than subjects who 'almost always' enjoyed their job tasks. However, there are limitations to the interpretation of this study. Only 1569 responded, and of these, 136 reported back pain; of the 1326 in whom complete data were available, 117 reported back pain. Regarding the statement 'I enjoy the tasks involved in my job' $18 \%$ of those who stated 'hardly ever' reported back pain over a four-year period compared with $14 \%$ and $7 \%$ reporting 'some of the time' and 'almost always', respectively. The study looked only at individuals who took time off for acute pain and did not deal with chronic disabling pain. Hales and Bernard (67) noted that the study of Bigos et al (65) did not investigate job or task demand stressors, and observed that most researchers considered job dissatisfaction to be a 'stress response' to factors in the workplace or a result of individual psychosocial stresses rather than a stress itself. The authors of the Boeing study (Bigos et al [65]) noted that the effect of work perceptions and psychosocial factors were "statistically significant though clinically modest".

Skovron et al (68), in a cross-sectional study of 4000 Belgian adults, found that work satisfaction was not associated with a first episode of LBP. However, poor work satisfaction was associated with a daily history of LBP among all working respondents with a history of LBP. The authors speculated that work satisfaction was not causally related to LBP but rather intervened with work to lead to an altered perception of work once LBP had developed. This speculation was notable in that the Bigos et al (65) study was confined to individuals who actually had sickness absence due to LBP. Hence, work dissatisfaction may lead individuals with LBP to take a few days off work but does not reveal the true incidence of LBP. Apart from the Bigos et al (65) study, other cross-sectional studies have found an association between work dissatisfaction or workplace stress and LBP (69-71). In contrast, one longitudinal study (72) and several cross-sectional studies (73-76) did not find an association (67). Thus, job dissatisfaction has yet to be shown to be causative of LBP, although this area remains controversial with conflicting data. The role of job dissatisfaction in chronic disability has not been adequately studied.

\section{Acknowledging uncertainty}

Pain is ordinarily held to be due to physical causes. If physical and psychological causes cannot be established to the satisfaction of the clinician, the only proper thing to do is to recognize that the cause of the pain has not been established. Judgement has to be suspended if a diagnosis cannot be made. The problem with reports such as Back Pain in the Workplace (5) is that they argue that pain (and subsequent disability) should be treated as if the illness is due to psychosocial factors. That is not to say that psychosocial factors are not important; however, psychosocial factors have been found to be important as contributors to disability in conditions that are far less controversial and better defined. One example recently studied is 
rheumatoid arthritis (77), a well-known cause of activity intolerance. Thus, biological possibilities are rejected, while the potential psychosocial factors operating in each case are assumed or overinferred. This is a violation of logic, which in Back Pain in the Workplace is justified on the grounds that treating chronic pain as disabling is too costly. In an attempt to make such an approach seem more palatable, this is reportedly done in the best interests of the patient (78). We will therefore next look at who is most likely to 'benefit' from proposed changes.

\section{WHO WILL BE AFFECTED BY PROPOSED CHANGES?}

Proposed changes to chronic pain disability compensation systems will most likely affect those in lower socioeconomic groups, in particular those who are poorly educated, lack transferable skills, are older and more likely to perform heavy or repetitive physical labour. Most of these would be classified as blue-collar workers or the 'working poor'. Attempts to deal with chronic pain disability as a social problem will target individuals who are especially vulnerable to withdrawal of support. This vulnerability is further enhanced by significant changes in the availability of work for individuals without specific technical skills and a decreasing willingness on the part of employers to accommodate compromised workers. Such factors are not confined to conditions such as NSLBP. For instance, Reisine et al (79) found that work autonomy (the ability to pace) and the physical nature of the job were more important than disease severity in determining work disability in rheumatoid arthritis patients. In a later study Reisine et al (77) pointed out that the complexity of the work itself, the desire to remain employed and reduced work hours influenced disability among rheumatoid arthritis patients.

\section{Type of work and disability}

Several reviews of LBP in workers indicate an association of heavy manual labour and LBP (80-83), and that such workers are more likely to develop compensable back injuries $(84,85)$. The three occupations at highest risk of compensable back injury are truck drivers (usually associated with loading and unloading trucks), material handlers and nursing aides. High risk occupations for back pain attributable to activities at work are construction labourers and carpenters for males, and nursing aides and maids for females (86). Leavitt (87) studied 1580 patients who presented with LBP in the office practices of 14 orthopedic groups who met study criteria and were working at the time of the injury. A total of 1191 (75\%) were injured at work, with over half involved in work requiring heavy physical exertion. In contrast, for workers injured outside of work there was no apparent relationship between exertion at work and presenting with an injury. Individuals in occupations involving heavy physical exertion were disabled for the longest time, whereas those involved in jobs requiring no physical exertion were disabled for the shortest time (87). The physical requirements of the job, the availability of appropriate or alternate work and the willingness of an employer to accommodate an injured employee's needs influence the degree of disability (2).

The importance of the physical demands of the job was borne out by a study conducted by Yelin et al (88) who reviewed data regarding 3100 adults with limitations in activities and chronic disease who had responded to the 1978 Social Security Administration
Survey of Disabled and Non-Disabled Adults. The authors looked at a variety of factors that correlated with work disability. They noted that, "the nature of the work itself had the most profound impact on whether the musculoskeletal disease patients stopped working after onset of the condition. Persons in white-collar occupations had far lower disability rates than others; persons in service occupations had far higher rates. Self-employment, too, reduced the probability of lost work. Among all the work variables, the interaction of the demands of the job and the limitations one experienced in performing them had the strongest effect among disability status" (88). The same authors noted that the impact of a change from good to poor working conditions had approximately 20 times the impact of a change from mild to severe symptoms, 16 times the impact of a change in all demographic characteristics associated with low and high disability rates and four times the impact of changes from good to poor work attitudes. Hence, work disability did not correlate well with the severity of symptoms but did with the physical demands of the workplace. This suggests that chronic pain tends to produce work disability primarily when the job is physically demanding, and the worker lacks autonomy (eg, is not self-employed); disability results more from the interaction of pain and the physical demands of the job than from the severity of the pain or the individual's work attitude. This study points out what has long been intuitively obvious but studiously ignored: the role that the physical demands of the injured worker's employment plays in chronic pain disability. Hence, disability is going to be affected by the ability of the individual to find alternative work or by the willingness and ability of the workplace to accommodate work restrictions. For such workers, significant alterations in the workplace over the past decade have been particularly harsh; 'right-sizing' and perhaps the increasing use of worker replacement technology have reduced the ability and willingness of the workplace to reabsorb injured workers.

\section{Lower socioeconomic status and disability}

Lower socioeconomic status has been shown to increase the frequency and severity of disability and the rate of progression to disability in patients with musculoskeletal disorders, including arthritic conditions (89-92). Badley and Ibanez (93) noted that several population studies have reported an increased frequency of chronic musculoskeletal disorders in individuals with lower levels of education and lower incomes (94-96). Verbrugge and colleagues (97) noted that lower socioeconomic status has been found to increase the risk of disability in individuals with musculoskeletal disorders. LBP is more common among those in lower socioeconomic groups compared with those in upper socioeconomic groups $(98,99)$, a trend likely to be attributable in large part to more physically demanding work (82). Gallagher et al (100) found that for LBP patients, the perception that a job change was difficult (transferrable skills) was associated with a reduced chance of returning to work by a factor of three.

As Badley and Ibanez (93) pointed out, musculoskeletal disorders are not unique in this association. Those of lower socioeconomic status report more chronic health conditions and are more likely to report lower functional status, greater limitation of daily activities and less good health $(101,102)$. Badley and Ibanez (93), in a cross-sectional survey of Canadian households (over 16 years), found disability was independently associated with increasing age, not being married, fewer years of schooling, lower income and not 
being employed. These risk factors were similar for both musculoskeletal and nonmusculoskeletal causes of disability. For instance, Krause and Anson (103) demonstrated that employment after spinal cord injury depended not only on the severity of the injury, but also on age and degree of education, with older, more poorly educated individuals being less likely to be employed. Badley and Ibanez (93) noted that, "discussion of the meaning of these associations needs to take into account the broader context of disability as a whole, rather than focussing solely on musculoskeletal disorders". They also note that it is "...likely that those with lower socioeconomic status carry a double jeopardy; not only is the risk of disease increased, but when it does occur there is also an increased risk of disability" (93). Patients in lower socioeconomic groups are not only employed in higher risk employment, but also are at higher risk of chronic disability once injured because they do not have the skills to enter readily into less physically demanding employment.

\section{Count the cost}

Attempts to deal with chronic pain and disability as social issues will disproportionately hurt poorer, older, less well educated individuals who lack transferrable skills and are least able to find alternative work. Out of economic necessity, such individuals will be more dependent on some form of compensation or income replacement. Several factors appear to be driving the push to reduce disability costs associated with chronic pain. One reason is the increasing costs associated with disability from chronic pain. As well, significant economic changes have taken place whereby the workplace is no longer able or willing to accommodate injured workers and alternative work is harder to come by. Also, in today's neoconservative political environment there appears to be less sympathy for those made more vulnerable through their injury because the 'bottom-line' continues to drive the containment of the costs of chronic pain. Reducing access to income replacement payments

\section{REFERENCES}

1. National Institutes of Health. Chronic pain: Hope Through Research. Publication no 82-2406. Bethesda: National Institutes of Health, 1982.

2. Sanders SH. Why do most patients with chronic pain not return to work? In: Cohen MJM, Campbell JN, eds. Pain Treatment Centers at a Crossroads: A Practical and Conceptual Reappraisal, Progress in Pain Research and Management, vol 7. Seattle: International Association for the Study of Pain Press, 1996:193-201.

3. World Health Organization. The International Classification of Impairments, Disabilities and Handicaps. Geneva: World Health Organization, 1980.

4. Hazard RG. Occupational low back pain: The critical role of functional goal setting. Am Pain Soc J 1994;3:101-6.

5. Fordyce WE, ed. Back Pain in the Workplace. Seattle: International Association for the Study of Pain Press, 1995.

6. Schrader H, Obelieniene D, Bovim G, et al. Natural evolution of late whiplash syndrome outside the medicolegal context. Lancet 1996;347:1207-11.

7. Spitzer WO, Skovron ML, Salmi LR, et al. Scientific monograph of the Quebec Task Force on Whiplash-Associated Disorders: redefining "whiplash" and its management. Spine 1995;20(Suppl 8):1S-73S.

8. Wolfe F, Smythe HA, Yunus MB, et al. The American College of Rheumatology 1990 criteria for the classification of fibromyalgia: Report of the Multicenter Criteria Committee. Arthritis Rheum 1990;33:160-72.

9. Diwaker HN, Stothard J. What do doctors mean by tenosynovitis and repetitive strain injury? Occup Med (Oxf) 1995;45:97-104.

10. Wolfe F, Simons DG, Fricton J, et al. The fibromyalgia and myofascial pain syndromes: a preliminary study of tender points and trigger points in persons with fibromyalgia, myofascial pain syndrome and no disease J Rheumatol 1992;19:944-51. will only serve to increase personal and family hardships for patients least able to cope with the loss of support, and is likely to transfer large portions of the problem to local welfare agencies. Remarkably, Fordyce (78), in Back Pain in the Workplace, recommended changing 'disability' status to that of 'unemployed' as "a way of helping to rescue the individual ... from ineffective, inappropriate and sometimes directly or indirectly harmful pathoanatomical interventions". We agree that the treatment of patients may be inappropriate and excessive at times, and it may be insufficient; however, it is likely that the conceptual change to "unemployed' status will only lead to withdrawal of benefits by thirdparty insurers and the jettisoning of responsibility for employees by employers. It is difficult to see how injured workers will benefit. Perhaps sensing the magnitude of such changes and its impact on injured individuals, Fordyce (78) later stated that it was "essential that 'unemployed' needs equivalent family support resources to that of disabled" (sic). It therefore remains unclear how society as a whole will benefit from simply withdrawing or reducing benefits to these patients.

\section{SUMMARY}

Chronic pain syndromes require further clarification and research. A wholesale denial of their validity as clinical or biological entities and recent attempts to classify chronic pain disorders as solely psychosocial issues are misguided, particularly in the light of the evidence of organic causes for chronic pain conditions. Such an approach runs the risk of hurting those patients who can least afford it - individuals who perform jobs with heavier physical demands, are less well educated, lack transferable skills, are older and in a lower socioeconomic class. It seems more appropriate to take account of the needs of the individual patient and the social costs of denying compensation, and to focus more on issues of work structure, and worker education and retraining.

11. Loeser JD, Sullivan M. Disability in the chronic low back pain patient may be iatrogenic. Pain Forum 1995;4:114-21.

12. Ochoa JL. Guest Editorial: Essence, investigation, and management of "neuropathic" pains: Hopes from acknowledgement of chaos. Muscle Nerve 1993;16:997-1008.

13. Spitzer WO, LeBlanc FF, Dupuis M. Scientific approach to the assessment and management of activity-related spinal disorders. Spine 1987;12:51-559.

14. Macnab I. The "whiplash syndrome". Orthop Clin North Am 1971;2:389-403.

15. Barnsley L, Lord S, Bogduk N. Comparative local anaesthetic blocks in the diagnosis of cervical zygapophyseal joint pain. Pain 1993;55:99-106.

16. Taylor JR, Twomey LT. Acute injuries to cervical joints. Spine 1993;18:1113-22.

17. Sturzenegger M, Radanov BP, DiStefano G. The effect of accident mechanisms and initial findings on the long term course of whiplash injury. J Neurol 1995;242:443-9.

18. Lord SM, Barnsley L, Wallis BJ, McDonald GJ, Bogduk N. Percutaneous radio-frequency neurotomy for chronic cervical zygapophyseal joint pain. N Engl J Med 1996;335:1721-6.

19. Littlejohn GO. Fibrositis/fibromyalgia syndrome in the workplace. Rheum Dis Clin North Am 1989;15:45-60.

20. McCain GA, Cameron R, Kennedy JC. The problem of long term disability payments and litigation in primary fibromyalgia: the Canadian perspective. J Rheumatology 1989;16(Suppl):174-6.

21. Reilly PA. Fibromyalgia in the workplace - a management problem. Ann Rheum Dis 1993;52:249-51.

22. Whorton D, Weisenberger BI, Milroy WC, et al. Does fibromyalgia qualify as a work-related illness or injury? J Occup Med 1992;34:968.

23. Bennett RM, Clark SR, Campbell SM, Burckhardt CS. Low levels of 
somatomedin $\mathrm{C}$ in patients with the fibromyalgia syndrome. A possible link between sleep and muscle pain. Arthritis Rheum 1992;35:1113-6.

24. McCain GA, Tilbe KS. Diurnal hormone variation in fibromyalgia syndrome. A comparison with rheumatoid arthritis. J Rheumatology 1989;19(Suppl):154-7.

25. Mountz JM, Bradley LA, Modell JG, et al. Fibromyalgia in women. Abnormalities of regional blood flow in the thalamus and the caudate nucleus are associated with low pain threshold levels. Arthritis Rheum 1995;38:926-38.

26. Russell IJ, Orr MD, Littman B, et al. Elevated cerebrospinal fluid levels of substance in patients with fibromyalgia syndrome. Arthritis Rheum 1994;37:1593-601

27. Yunus MB, Dailey JW, Aldag DC, et al. Plasma tryptophan and other amino acids in primary fibromyalgia. A controlled study. J Rheumatology 1992;19:90-4.

28. Bradley RA, Alberts KR, Alarcon GC, et al. Abnormal brain regional cerebral blood flow (rCBF) and cerebrospinal fluid (CSF) levels of substance $\mathrm{P}$ (SP) inpatients and non-patients with fibromyalgia (FM). Arthritis Rheum 1996;39(9S):S212.

29. Vaeroy H, Helle R, Forre O, Kass E, Terenius L. Elevated CSF levels of substance $\mathrm{P}$ and high incidence of Raynaud's phenomenon in patients with fibromyalgia: new features for diagnostics. Pain 1988;32:21-6.

30. Wall PD. The dorsal horn. In: Wall PD, Melzack RA, eds. Textbook of Pain, 1st edn. London: Churchill-Livingstone, 1984:80-7.

31. Mense S. Referral of muscle pain. Am Pain Soc J 1994;3:10-2.

32. Hockaday JM, Whitty CWM. Patterns of referred pain in the normal subject. Brain 1967;90:481-96.

33. Inman VH, Saunders JB. Referred pain from skeletal structures. J Nerve Ment Dis 1944;99:660-97.

34. Kellgren JH. Observations on referred pain arising from muscle. Clin Sci 1938;3:175-90.

35. Sinclair DC, Wedell G, Feindel WH. Referred pain and associated phenomena. Brain 1948;71:184-211.

36. Molander C, Ygge I, Dalsgaard C-J. Substance P, somatostatin- and calcitonin gene-related peptide-like immunoreactivity and fluoride resistant acid phosphatase-activity in relation to retrogradely labelled cutaneous, muscular and visceral primary sensory neurons in the rat. Neurosci Lett 1987;74:34-42.

37. Sastry BR. Substance P effects on spinal nociceptive neurones. Life Sci 1979;24:2169-78.

38. Zieglgansberger W, Tulloch IF. Effects of substance $\mathrm{P}$ on neurones in the dorsal horn of the spinal

39. Agnati LF, Fuxe K, Zoli M, et al. A correlation analysis of the regional distribution of central enkephalin and beta-endorphin immunoreactive terminals and of opiate receptors in adult and old male rats. Evidence for the existence of two main types of communication in the central nervous system: the volume transmission and the wiring transmission. Acta Physiol Scand 1986;128:201-7.

40. Coderre TJ, Katz J, Vaccarino AL, Melzack R. Contribution of central neuroplasticity to pathological pain: review of clinical and experimental evidence. Pain 1993;52:259-85.

41. Gamsa A. Is emotional status a precipitator or a consequence of pain? Pain 1990;42:183-95

42. Crook J, Tunks E. Defining the "chronic pain syndrome": An epidemiological method. In: Fields HL, Dubner R, Cervero F, eds. Advances in Pain Research and Therapy, vol 9. New York: Raven Press, 1986:871-7.

43. Merskey H, Brown J, Brown A, Malhotra D, Morrison D, Ripley D. Psychological normality and abnormality in persistent headache patients. Pain 1985;23:35-47.

44. Merskey H, Lau CL, Russell ES, et al. Screening for psychiatric morbidity. The pattern of psychological illness and pre-morbid characteristics in four chronic pain populations. Pain 1987;30:141-57.

45. Dworkin DH, Handlin D, Richlin D, Brand L, Vannuci C. Unravelling the effects of compensation, litigation and employment on treatment response in chronic pain. Pain 1985;23:49-59.

46. Melzack RA, Katz J, Jeans ME. The role of compensation in chronic pain: analysis using a new method of scoring the McGill Pain Questionnaire. Pain 1985;23:101-12.

47. Tait RC, Chibnall JD, Richardson WD. Litigation and employment status: effects on patients with chronic pain. Pain 1990;43:37-46.

48. Polley HF, Svenson WM, Steinhilber RM. Personality characteristics of patients with rheumatoid arthritis. Psychosomatics 1970;11:45-9.

49. Robinson H, Kirk RF, Frye RL. A psychological study of rheumatoid arthritis and selected controls. J Chron Dis 1971;23:791-801.

50. Zaphiropoulos G, Burry HC. Depression in rheumatoid disease. Ann Rheum Dis 1974;33:132-5.
51. Charter RA, Nehremkis AM, Kennan MA, Person D, Prete PE. The nature of arthritic pain. Br J Rheumatol 1985;24:53-60.

52. Deyo RA, Inui TS, Leininger J, Overman S. Physical and psychosocial function in rheumatoid arthritis: clinical use of a self-administered health status instrument. Arch Intern Med 1982;142:879-82.

53. Richards JS, Meredith RL, Nepomuceno C, Fine PR, Bennett G. Psycho-social aspects of chronic pain in spinal cord injury. Pain 1980;8:355-66.

54. Rose M, Robinson JE, Ells P, Cole JD. Pain following spinal cord injury: results from a postal survey. Pain 1988;34:101-2.

55. Sauter S, Swanson N. The relationship between work place psychosocial factors and musculoskeletal disorders in office work: Suggested mechanisms and evidence. In: Gordon S, Blair S, Fine L, eds. Repetitive Motion Disorders of the Upper Extremity. Rosemont: American Academy of Orthopaedic Surgeons, 1994:65-76.

56. Gatchel RJ, Polatin PB, Mayer TG. The dominant role of psychosocial risk factors in the development of chronic low back pain disability Spine 1995;20:2702-9.

57. Smythe HA. Problems with the MMPI. J Rheumatology 1984;11:417-8.

58. Watson D. Neurotic tendencies among chronic pain patients: an MMPI item analysis. Pain 1982;14:365-85.

59. Radanov BP, Sturzenegger M, DeStefano G, Schindrig A. Relationship between early somatic, radiological, cognitive and psychosocial findings and outcome during a one-year follow-up in 117 patients suffering from common whiplash. Br J Rheumatology 1994;33:442-8.

60. Miller HG. Accident neurosis. BMJ 1961:i:919-25,992-8.

61. Mendelson G. Not "cured by a verdict". Effect of legal settlement on compensation claimants. Med J Austr 1982;2:219-30.

62. Rohling ML, Binder LM, Langhinrichsen-Rohling J. Money matters: A meta-analytic review of the association between financial compensation and the experience and treatment of chronic pain. Health Psychol 1995;14:537-47.

63. Fishbain DA. Secondary gain concept. Definition problems and its abuse in medical practice. Am Pain Soc J 1994;3:264-73.

64. Freeman DW. Sick rule dynamics and chronic back pain in the injured worker. Seventh World Congress on Pain, Paris, France, 1993. (Abst 315:108)

65. Bigos SJ, Battie MC, Spengler DM, et al. A prospective study of work perceptions and psychosocial factors affecting the report of back injury. Spine 1991;16:1-6.

66. Bigos SJ, Battie MC, Spengler DM, et al. A longitudinal, prospective study of industrial back injury reporting. Clin Orthop 1992;279:21-34.

67. Hales TR, Bernard BP. Epidemiology of work-related musculoskeletal disorders. Orthop Clin North Am 1996;27:679-709.

68. Skovron ML, Szpalski M, Nordin M, Melot C, Cukier D. Sociocultural factors in back pain: A population based study in Belgian adults. Spine 1994; 19:129-37.

69. Heliovaara M, Makela M, Knekt P, et al. Determinants of sciatica and low back pain. Spine 1991;16:608-14.

70. Svensson H-O, Andersson GBJ. Low back pain in 40 to 47 year old men: Work history and work environment factors. Spine 1983;8:272-6.

71. Svensson H-O, Andersson GBJ. The relationship of low back pain, work history and work environment, and stress: A retrospective cross-sectiona study of 38-64 year old women. Spine 1989;14:517-22.

72. Beiring-Sorenson F, Thomsen CE, Hilden J. Risk indicators for low back trouble. Scand J Rehab Med 1989;21:151-7.

73. Astrand NE. Medical, psychological, and social factors associated with back abnormalities and self-reported back pain: A cross-sectional study of male employees in a Swedish pulp and paper industry. Br J Ind Med 1987;44:327-36

74. Feyer AM, Williamson A, Mandryk J, et al. Role of psychosocial risk factors in work-related low back pain. Scand J Work Environ Health 1982; $18: 368-75$

75. Linton SJ. Risk factors for neck and back pain in a working population in Sweden. Work and Stress 1990;4:41-9.

76. Skrovron ML, Mulvihill MN, Sterling RC, et al. Work organization and low back pain in nursing personnel. Ergonomics 1987;30:359-66.

77. Reisine S, McQuillan J, Fifield J. Predictors of work disability in rheumatoid arthritis patients. A five year follow-up. Arthritis Rheum 1995;38:1630-7.

78. Fordyce WE. Response to Thompson/Merskey/Teasell. Pain 1996;65:112-4. (Lett)

79. Reisine ST, Grady KE, Goodenow C, Fifield J. Work disability among women with rheumatoid arthritis. Arthritis Rheum 1989;32:538-43.

80. Frymoyer JW, Pope MH, Clements JH. Risk factors in low back pain J Bone Joint Surg 1983;65:213.

81. Garg A, Moore SJ. Epidemiology of low-back pain in industry. In: Moore SJ, Garg A, eds. Occupational Medicine, State of the Art 
Reviews. Ergonomics: Low-back pain, Carpal Tunnel Syndrome, and Upper Extremity Disorders in the Workplace. Philadelphia: Hanley \& Belfus, 1992:599-608.

82. Kelsey JL, Golden AL. Occupational and workplace factors associated with low back pain. In: Deyo RA, ed. Occupational Medicine, State of the Art Reviews: Back Pain in Workers. Philadelphia: Hanley \& Belfus, 1988:7-16.

83. Snook SH. Low back pain in industry: In: White AA, Gordon SL, eds. American Academy of Orthopaedic Surgeons Symposium on Idiopathic Low Back Pain. St Louis: CV Mosby, 1982:23-38.

84. Bergqvist-Ullman M, Larson N. Acute low back pain in industry. Acta Orthop Scand 1977;170(Suppl):1-117.

85. Jensen RC. Epidemiology of work-related back pain. Topics Acute Care Trauma Rehab 1988;2:1-15.

86. Guo H-R, Tanaka S, Cameron LL, et al. Back pain among workers in the United States: National estimates and workers at high risk. Am J Industrial Med 1995;28:591-602.

87. Leavitt F. The physical exertion factor in compensable work injuries. A hidden flaw in previous research. Spine 1992;17:307-400.

88. Yelin EH, Henke CJ, Epstein WV. Work disability among persons with musculoskeletal conditions. Arthritis Rheum 1986;29:1322-33.

89. Deyo RA, Diehl AK. Psychosocial predictors of disability in patients with low back pain. J Rheumatol 1988;15:1957-64.

90. Leigh JP, Fries JF. Occupation income, and education as independent covariates of arthritis in four national probability samples. Arthritis Rheum 1991;34:974-95.

91. Leigh JP, Fries JF. Predictors of disability in a longitudinal sample of patients with rheumatoid arthritis. Ann Rheum Dis 1992;51:581-7.
92. Pincus T, Callahan LF. Formal education as a marker for increased mortality and morbidity in rheumatoid arthritis. J Chronic Dis 1985;38:973-84.

93. Badley EM, Ibanez D. Socioeconomic risk factors and musculoskeletal disability. J Rheumatol 1994;21:515-21.

94. LaVecchia C, Negri E, Pagano R, Decarli A. Education, prevalence of disease, and frequency of health care utilization. J Epidemiol Commun Health 1987;41:161-5.

95. Leigh JP, Fries JF. Education level and rheumatoid arthritis: Evidence from five data centers. J Rheumatol 1991;18:24-34.

96. Pincus T, Callahan LF, Burkhauser RV. Most chronic diseases are reported more frequently by individuals with fewer than 12 years of formal education in the age 18-64 United States population. J Chronic Dis 1987;40:865-74.

97. Verbrugge LM, Gates GM, Ike RW. Risk factors for disability among U.S. adults with arthritis. J Clin Epidemiol 1991;44:167-82.

98. Nagi SZ, Riley LE, Newby LG. A social epidemiology of back pain in a general population. J Chronic Dis 1973;26:769.

99. Reisbord LS, Greenland S. Factors associated with self-reported backpain prevalence: a population-based study. J Chronic Dis 1985;38:691.

100. Gallagher R, Rauh V, Haugh L, et al. Determinants of return to work among low back pain patients. Pain 1989;39:55-67.

101. Blaxter M. Health and social class: Evidence on inequality in health from a national survey. Lancet 1987;ii:30-3.

102. House JS, Kessler Rc, Herzog AR, et al. Age, socioeconomic status, and health. Milbank Q 1990;68:383-411.

103. Krause JS, Anson CA. Employment after spinal cord injury: relation to selected participant characteristics. Arch Phys Med Rehabil 1996;77:737-43. 


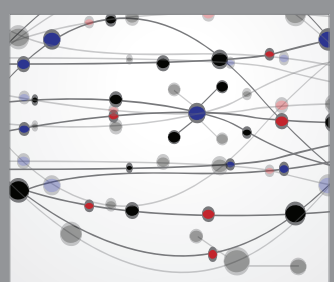

The Scientific World Journal
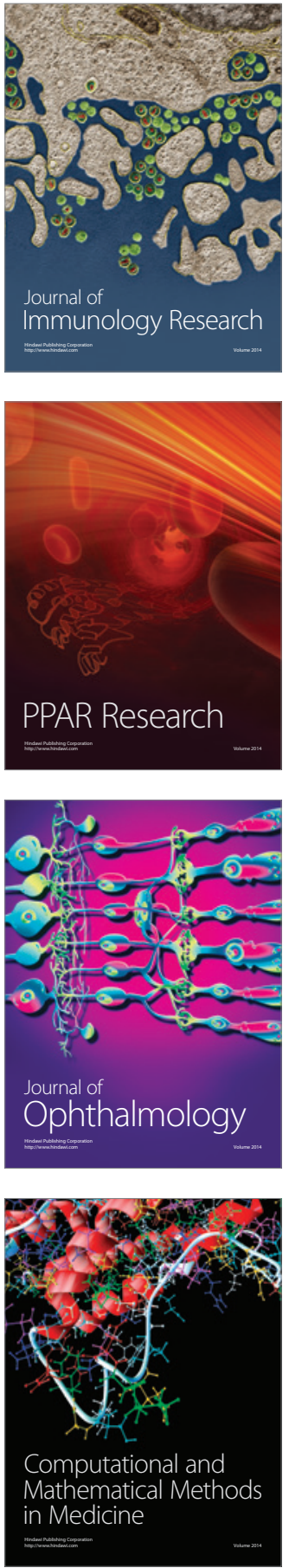

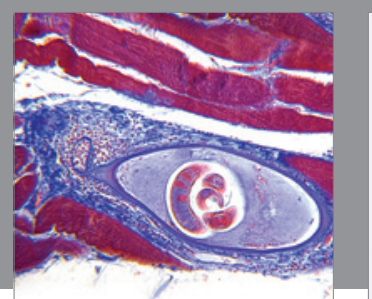

Gastroenterology Research and Practice

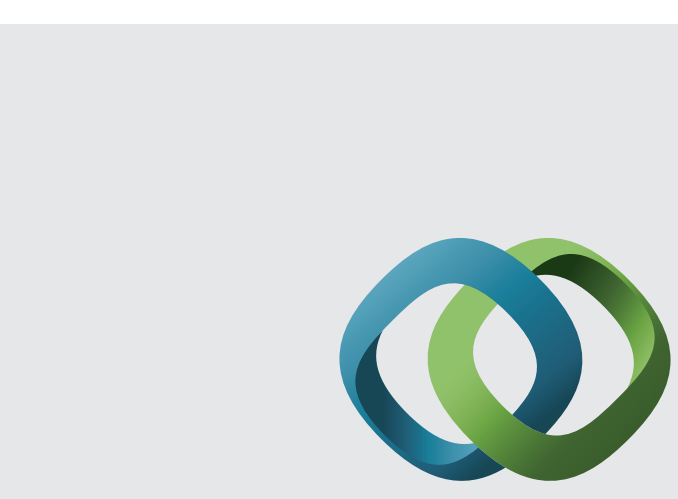

\section{Hindawi}

Submit your manuscripts at

http://www.hindawi.com
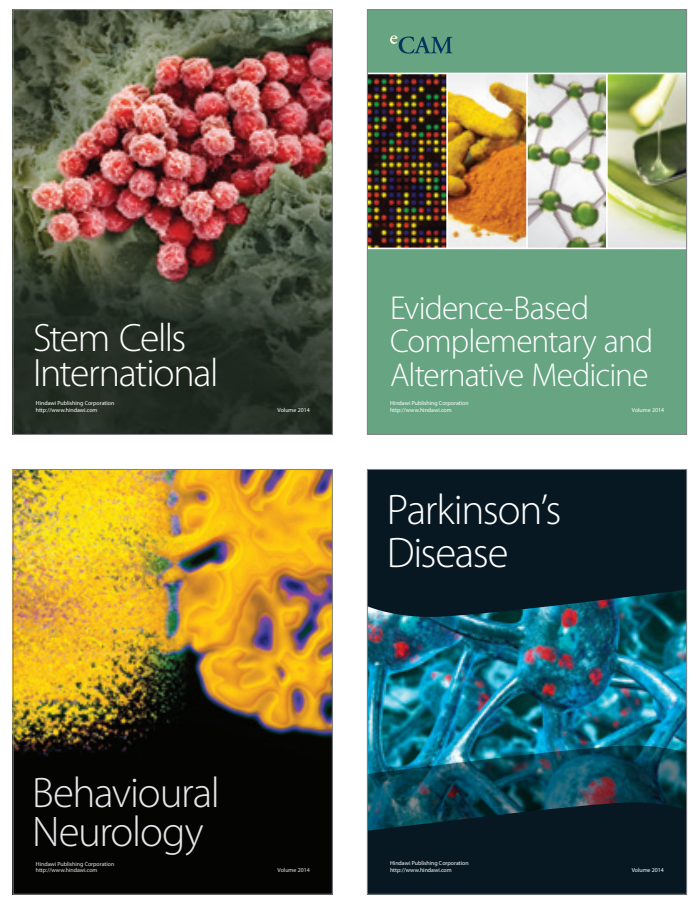
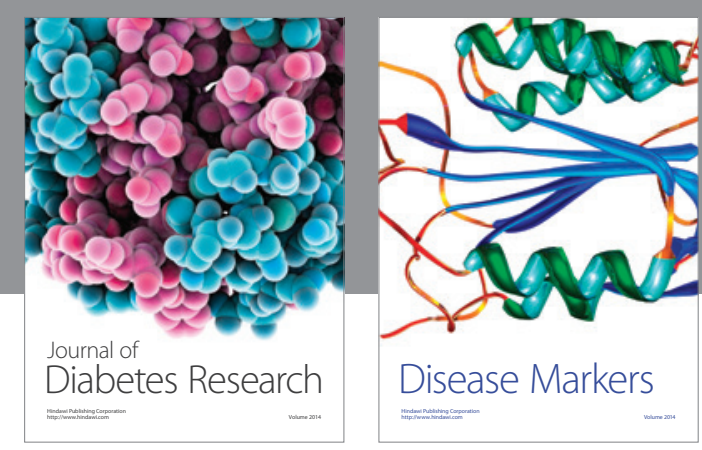

Disease Markers
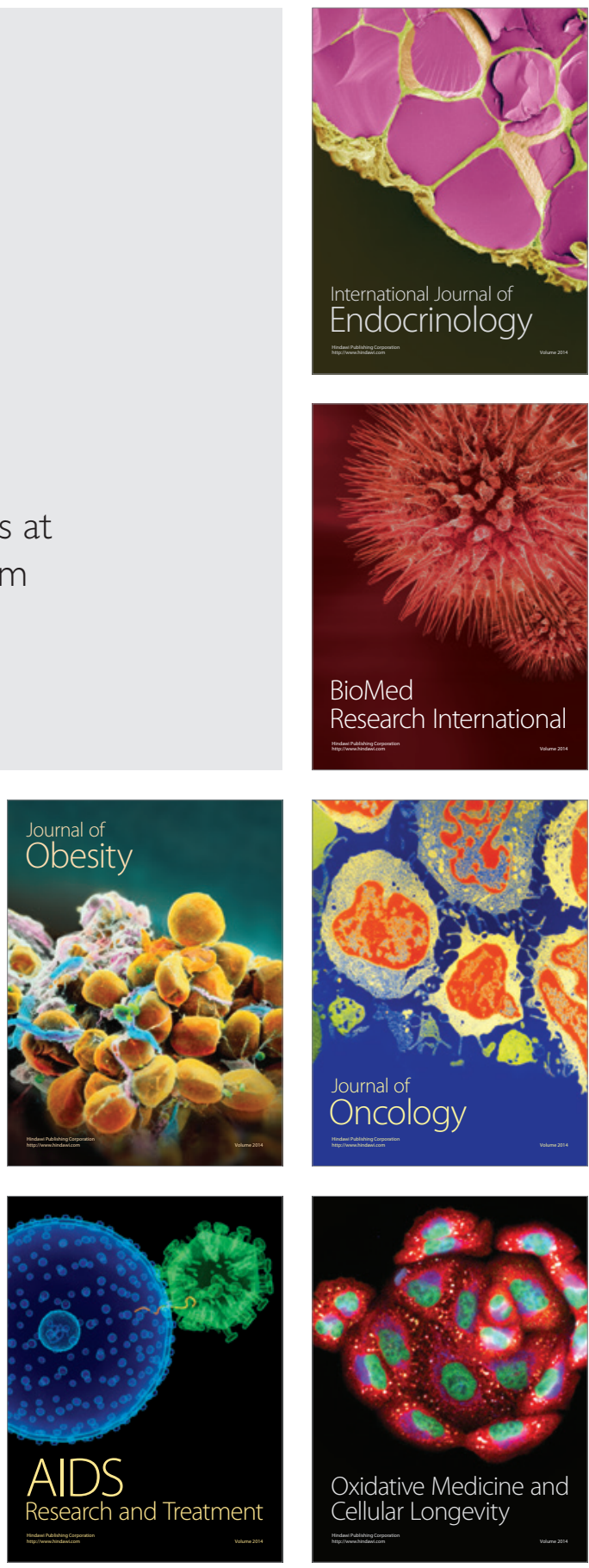